\title{
Pengaruh Pembiayaan Bank Islam, FDI dan Pertumbuhan Ekonomi: Studi Empiris Negara OKI
}

\author{
${ }^{1 *}$ Annisa Masruri Zaimsyaha, ${ }^{2}$ Sri Herianingrum \\ ${ }^{1,2}$ Sains Ekonomi Islam, Fakultas Ekonomi dan Bisnis, Universitas Airlangga, Indonesia \\ *Email korenpondensi: annisa.masruri.zaimsyah-2018@pasca.unair.ac.id
}

\begin{abstract}
The purpose of this study is studying influence between financing of Islamic Banks, FDI and Economic Growth. The methodology used is a quantitative method usning panel data. We have chosen 10 counties from Organization Islamic Conference (OIC) over the period 2009-2017. The research is the fist study to influence financing of Islamic Bank, FDI and Economic Growth in OIC Countries. The result show that the financing of Islamic Banks and FDI simultaneously and positively has a significant effect on economic growth in the OIC Countries with a significant level of 0.0000.
\end{abstract}

Keywords: Pembaiayaan Bank Islam, FDI, PDB, OKI

Saran sitasi: Zaimsyaha, A., \& Herianingrum, S. (2019). Pengaruh Pembiayaan Bank Islam, FDI dan Pertumbuhan Ekonomi: Studi Empiris Negara OKI. Jurnal Ilmiah Ekonomi Islam, 5(03), 211-216. doi: http://dx.doi.org/10.29040/jiei.v5i3.524

DOI: http://dx.doi.org/10.29040/jiei.v5i3.524

\section{Pendahuluan}

Ilmuan ekonomi telah melakukan penelitian mengenai ekspansi ekploitasi lembaga keuangan dalam alokasi sumber daya pertumbuhan ekonomi (Zarrouk, Ghak, \& Haija, 2017). Hubungan pertumbuhan keuangan telah banyak dikaji dalam literatur, dengan bukti beragam: Beberapa penelitian menjangkau konflik bahwa perkembangan keuangan (Caporale \& Helmi, 2018). Dari sekian banyak peneltian yang dilakukan dibidang ini, setidaknya ada tiga jenis hubungan antara pengembangan keuangan dan pertumbuhan ekonomi yang ditemukan yaitu Supply-Leading, demand dan hubungan kausal directional (Abduh \& Chowdhury, 2012).

Dalam dua dekade terakhir ini, industri keuangan Islam telah berkembang di dunia ini. Asset perbankan syariah telah berkembang sangat pesat. Asset perbankan syariah internasional dengan bank-bank komersial diperkirakan akan melebihi US \$778 miliyar di 2014. Secara khusus, emam Negara yaitu Qatar, Indonesia, Arab Saudi, Malaysia, Uni Emirat Arab (UEA) dan Turki hampir menyentuh US $\$ 1,8$ Triliun di tahun 2019. Kinerja yang stabil relatif lembaga-lembaga keuangan Islam selama krisis keuangan yang melanda dunia pada tahun 2008 meningkatkan permintaan produk-produk yang sesuai dengan syariah, tidak hanya para penyedia keuangan di Timur Tengah tetapi juga Negara-negara lain yang berinvestasi diseluruh dunia (Zarrouk, Ghak, \& Haija, 2017).

Penelitian empiris terkait keuangan telah banyak diteliti. Model teoritis ditingkatkan untuk menunjukkan bahwa perbankan Islam yang berpengaruh signifikan terhadap komponen keuangan yang lebih disukai dibandingkan dengan keuangan tradisional untuk stabilitas dan efisiensi ekuitas. Sebagian besar peneliti telah menekankan pentingnya pertumbuhan ekonomi 
perbankan syariah dalam meningkatkan pertumbuhan ekonomi. Selain dari Perbankan Islam, Teori ekonomi menunjukkan bahwa investasi adalah mesin pertumbuhan ekonomi, akan tetapi Negara berkembang memiliki masalah dalam mempersiapkan dana investasi. Salah satu solusinya adalah meminjam dari luar negeri tetapi akan berakibat terjadinya krisis terhadap pembayaran peminjaman. Oleh karena itu, saat ini FDI adalah pilihan yang paling tepat untuk mempersiapkan modal untuk Negara yang berkembang (Tajgardoon, Noormohamadi, \& Behname, 2015). Negara anggota Organisasi Konferensi Islam (OKI) dalam dua dekade ini memiliki pertumbuhan yang sangat pesat di pasar keuangan, sistem perbankan, dan arus saham yang masuk ke FDI (UNCTAD, 2000). Oleh karena itu, kita dapat menemukan hubungan positif antara pasar keuangan dan FDI (Tajgardoon, Noormohamadi, \& Behname, 2015). Ketika sektor keuagan lebih berkembang, banyak sumber daya keuangan yang dapat dialokasikan ke dalam investasi riil produktif dan lebih banyak modal yang berbentuk fisik yang dapat meningkatkan pertumbuhan ekonomi. FDI diartikan sebagai penanaman modal dalam jangka panjang ke sebuah perusahaan Negara lain.

Investasi Langsung Asing (FDI) yang mengalir sebesar US $\$ 1,56$ triliun pada 2014, kegiatan perusahaan multinasional memiliki kemampuan untuk secara signifikan mempengaruhi hasil ekonomi di negara tuan rumah (Owen, 2018). Investasi langsung merupakan faktor penting untuk pertumbuhan ekonomi. Khususnya, untuk mengembangkan perekonomian di mana kendala keuangan lebih tinggi untuk perusahaan domestik yang menghambat produktivitas mereka (Rehman, 2015)

Akhir-akhir ini, negara-negara berkembang menerapkan penghalang untuk mencegah investasi langsung asing, tetapi setelah tahun 1980-an negara-negara ini mengakui pengakuan atas solusi untuk FDI dan solusinya. FDI telah mulai tumbuh sehingga pertumbuhan FDI telah lebih dari pertumbuhan ekspor, impor dan PDB di dunia ekonomi yang menunjukkan bahwa investasi adalah mesin pertumbuhan ekonomi. Salah satu solusinya adalah meminjam dari luar negeri untuk menyiapkan dana investasi. Oleh karena itu, FDI saat ini adalah pilihan paling banyak untuk mempersiapkan modal di negaranegara berkembang. Setelah tahun-tahun ini FDI telah mulai pertumbuhan cepat sehingga pertumbuhan FDI telah lebih dari pertumbuhan ekspor, impor dan PDB di Dunia (Tajgardoon, Noormohamadi, \& Behname, 2015)

Begitu juga dengan fungsi bank, bank berfungsi mengumpulkan simpanan dari rumah tangga, perusahaan dan menggunakan simpanan tersebut untuk keperluan bisnis dan rumah tangga yang dikeluarkan berbentuk pembiayaan (Cetin, 2014), keuntungan yang banyak dari bank syariah adalah dari pembiayaan yang dikeluarkan oleh bank tersebut.

Penelitian oleh Nantwi mengatakan bahwa adanya hubungan jangka panjang antara FDI pada pertumbuhan ekonomi di Amerika Selatan. Hasil VECM menemukan hubungan jangka pendek dua arah atara FDI dan Pertumbuhan Ekonomi (Owusu-Nantwi \& Erickson, 2019)

Cetin (2014) menyatakan bahwa misi penting lembaga perbankan adalah untuk mendapatkan simpanan dari nasabah, perusahaan dan menggunakan dana untuk keperluan bisnis nasabah. Bank syariah secara fundamental mendapatkan sorotan dari rumah tangga dan perusahaan untuk menggunakan dana pinjaman dari bank untuk pertumbuhan volume bisnis dan untuk produksi. Bank syariah tidak memberikan kredit langsung dengan suku bunga dan berpartisipasi untuk menambah laba (Cetin, 2014).

Penelitian Cholamreza, Noormahamadi dan Behname (2012), yang berjudul Foreign Direct Investment and Islamic Banking: A Granger Causality Test, mengatakan bahwa dengan uji Kausalitas dalam jangan pendek menunjukkan bahwa ada hubungan umpan balik antara perbankan Islam dan investasi asing langsung, ini berarti penguatan perbankan Islam 
bergantung pada FDI. Dalam penelitian ini juga menunjukkan bahwa penguatan FDI dan Perbankan Islam dapat mencurahkan perhatian pada perbankan Islam di Negara-negara Islam untuk FDI.

Sektor keuangan dan perhubungan pertumbuhan ekonomi telah menarik banyak minat akademisi. Menghubungkan sektor pengawasan yang dibenarkan oleh lembaga keuangan memiliki pengaruh yang jelas terhadap dua komponen utama dari output suatu negara: tabungan dan investasi, dan kadang-kadang juga memengaruhi pertumbuhan (Lebdaoui, 2015).

Sehingga, penelitian ini akan melihat bagaimana pengaruh Pembiayaan Bank Islam dan FDI terhadap Pertumbuhan Ekonomi yang di ambil dari nilai PDB per Kapita di Negara OKI pasca krisis dari tahun 2009-2017. Penelitian ini merupakan penelitian pertama yang melihat pengaruh antara Aset Bank Islam dan FDI terhadap Pertumbuhan Ekonomi.

Dari model ini maka hipotesis yang digunakan dalam penelitian ini sebagai berikut:

$\mathrm{H}_{0}=$ Tidak ada kointegrasi antara Bank Islam,

FDI dan Pertumbuhan Ekonomi

$\mathrm{H}_{\mathrm{a}}=$ Ada Kointegrasi antara Bank Islam, FDI dan Pertumbuhan Ekonomi

\section{Metode Penelitian}

\subsection{Sumber dan Jenis Data}

Data yang digunakan dalam penelitian ini adalah data sekunder dari Pembiayaan dan Investasi Bank Islam yang diambil dari annual report perbankan Islam setiap Negara, FDI yang diambil dari indikator world Bank, dan PDB per kapita, yang diambil dari Indikator world bank. PDB per kapita dapat menggambarkan keadaan pertumbuhan ekonomi sesungguhnya. Sampel untuk penelitian ini adalah Negara yang tergabung dalam OKI, akan tetapi hanya 10 negara yang diteliti dikarenakan kurang lengkapnya data untuk semua Negara OKI, hanya 10 negara inilah yang memenuhi data untuk diteliti. Negara-negara tersebut adalah, Indonesia, Malaysia, Turkey, Qatar, Khazakhstan, Bahrain, Algeria, Jordan, Sudan, dan Pakistan.

\subsection{Metode Pengumpulan Data}

Teknik Pengumpulan data yang digunakan dalam penelitian ini adalah dengan cara dokumentasi. Dokumentasi adalah catatan peristiwa yang sudah berlalu dan merupakan sarana pembantu peneliti dalam mengumpulkan daya dan informasi dengan cara membaca jurnaljurnal, buku, berita website World Bank dan Sesric.

\subsection{Definisi Operasional Variabel}

\section{Tabel 1. Definisi Operasional Variabel}

\begin{tabular}{llll}
\hline Vaeiabel & Definisi & Sumber Data \\
\hline Asset Bank Islam & Bank Islam adalah bank yang yang tata cara & Annual report \\
& beroperasinya didasarkan pada tata cara bermu'malat & setiap Bank Islam \\
& sesuai ajaran agama Islam, dan berbeda dengan Bank & \\
& konvensional atau Bank non-Islam & \\
FDI & Dana Moneter Internasional, database Neraca Indikator World & Pank \\
& Pembayaran, ditambah dengan data dari Konferensi & Bank \\
& PBB tentang Perdagangan dan Pembangunan dan & \\
Pertumbuhan & sumber-sumber resmi nasional. & Indikator World \\
Ekonomi (GDPPP) & Produk domestik bruto dibagi dengan populasi & Bank \\
\hline
\end{tabular}

\subsection{Metode Analisis Data}

Penelitian ini menggunakan analisis regresi linier berganda. Analisis regresi linier berganda adalah regresi dimana variable endogen (Y) dihubungkan atau dijelaskan lebih dari satu variabel. Adapun perumusan analisis ini yautu menggunakan metode Ordanary Least Square (OLS) sebagai berikut:

$\mathrm{Y}=\alpha+\beta_{1} \mathrm{X} 1+\beta_{2} \mathrm{X}_{2}+\mathrm{e}$

Keterangan: 


\section{Jurnal Ilmiah Ekonomi Islam, 5(03), 2019, 214}

$\mathrm{Y}=$ Pertumbuhan Ekonomi

$\alpha=$ Bilangan Konstanta

$\beta=$ Koefisien Variabel

$\mathrm{X} 1$ = Aset Bank Islam

$\mathrm{X} 2=\mathrm{FDI}$

$\mathrm{e} \quad=$ Kesalahan Penganggu

Dalam melakukan analisis data pada penelitian ini, ada beberapa bentuk uji yang digunkan, yaitu uji asumsi klasik dan uji hipotesis. Uji asumsi klasik antara lain uji normalitas, uji multikolinieritas, uji autokorelasi, dan uji heteroskedasitas. Uji hipotesis antara lain uji t (parsial, uji $\mathrm{F}$ (simultan) dan uji Koefisien determinasi $\left(\mathrm{R}^{2}\right)$.

Model penelitian sebagai berikut:

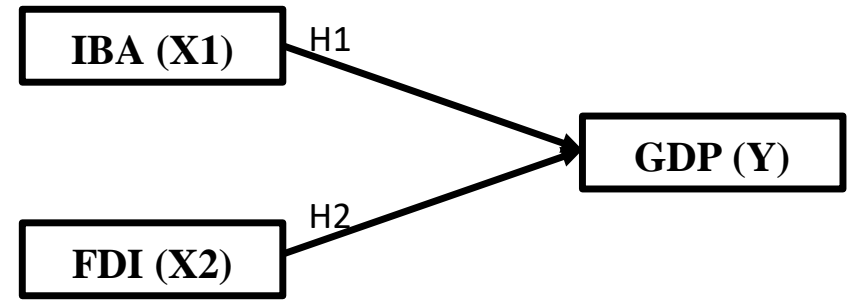

Hipotesis:

H1: Pembiayaan bank Islam memiliki pengaruh positif terhadap Pertumbuhan ekonomi

H2: FDI memiliki pengaruh positif terhadap

Pertumbuhan Ekonomi

\section{Hasil dan Pembahasan}

\subsection{Hasil Penelitian}

Dalam penelitian ini menggunakan data Pembiayaan dan Investasi Bank Islam dari annual report masing-masing perbankan Islam yang ada di Negara-negara OKI dan data FDI dan Pertumbuhan Ekonomi yang diambil dari Produk Domestik Bruto (PDB) per kapita yang didapatkan dari Indicator World Bank.

\subsubsection{Asumsi-Asumsi Klasik Regresi}

Hasil uji asumsi klasik yang terdiri dari uji normalitas, multikolinieritas, autokorelasi, dan heteroskedasitas dapat terpenuhi dan layak atau sudah tepat. Sehingga dapat diambil interpretasi dari hasil analisis regresi berganda telah dilakukan.

\subsubsection{Hasil Analisis Regresi Linier Berganda}

Berdasarkan tabel 2 didapatkan persamaan sebagai berikut:

$Y=8674.608+0.0000293 X 1+2.38 E+07 X 2$
Tabel 2. Analisis Regresi Linier Berganda

\begin{tabular}{lllll}
\hline Model & $\begin{array}{l}\text { Std } \\
\text { Error }\end{array}$ & $\begin{array}{l}\text { Standar } \\
\text { Coefficient }\end{array}$ & t & Prof \\
\hline $\mathrm{C}$ & 2197.958 & 8674.608 & 3.946666 & 0.0002 \\
\hline $\mathrm{X} 1$ & $2.75-\mathrm{E} 05$ & 0.029300 & 10.676595 & 0.0000 \\
\hline $\mathrm{X} 2$ & $2.28 \mathrm{E}+07$ & $2.38 \mathrm{E}+07$ & 1.043192 & 0.0297 \\
\hline
\end{tabular}

Sumber: Eviews 9 (diolah)

Persamaan regeresi di atas dapat dijelaskan sebagai berikut:

a. Konstanta sebesar 8674.608 artinya jika nilai IB (X1) dan FDI (X2) adalah 0, maka PDB (Y) nilainya sebesar 8674.608

b. Koefisien IB (X1) sebesar 0.029300 artinya jika Pembiayaan yang diberikan Bank Islam mengalami kenaikan 1\% maka PDB akan mengalami kenaikan sebesar $0.029300 \%$ dengan asumsi variable eksegon lainnya tetap. Koefisien bernilai positif artinya hubungan positif antara Pembiayaan Bank Islam dengan Pertumbuhan Ekonomi (Y) nilainya sebesar 1.824892 .

c. Koefisien regresi FDI (X2) sebesar 2.383E+07 artinya jika FDI mengalami kenaikan 1\% maka PDB (Y) akan mengalami kenaikan sebesar 2.383E+07\% dengan asumsi variable eksigen lainnya tetap. Koefisien bernilai positif artinya hubungan positif antara FDI dan PDB, semakin naik FDI maka semakin naik PDB.

\subsubsection{Hasil Uji Koefisien Determinasi $\left(\mathbf{R}^{2}\right)$}

Koefisien determinasi $\left(\mathrm{R}^{2}\right)$ digunakan untuk mengetahui persentase sumbangan pengaruh serentak variable-variabel eksogen $(\mathrm{X})$ terhadap variable endogen (Y). besarnya koefisien determinasi $\left(\mathrm{R}^{2}\right)$ antara 0 sampai dengan 1 . Berdasarkan tampilan output eviews 9 diperoleh bahwa nilai $\mathrm{R}^{2}$ Pertumbuhan ekonomi (PDB) sebesar 0.583736 atau $58.37 \%$ angka tersebut menyebutkan bahwa variable eksogen (X1 dan X2) terhadap variable endogen (Y) sebesar $58.37 \%$. sedangkan sisanya $41.63 \%$ dipengaruhi oleh variable lain yang tidak diteliti.

Tabel 2. Hasil Uji $\mathbf{R}^{2}$

\begin{tabular}{lll}
\hline Model & R Square & Adjusted R Square \\
\hline $\mathbf{1}$ & 0.583736 & 0.574167 \\
& Sumber: Eviews 9 (diolah)
\end{tabular}




\subsubsection{Hasil Uji F}

Pengujian ini terhadap koefisien regresi secara simultan dilakjukan dengan uji $F$. pengujian ini dilakukan untuk mengetahui pengaruh semua variable eksogen yang terdapat di dalam model secara bersama-sama (simultan) terhadap variable endogen. Dengan tingkat signifikan sebesar $5 \%$ bilai $\mathrm{F}$ rasio $>\mathrm{F}$ table atau prob-sig $<\alpha=5 \%$ berarti bahwa masing-masing variable eksogen berpengaruh secara positif terhadap variable endogen.

Tabel 3. Hasil Uji F

\begin{tabular}{lll}
\hline Model & F-Statistik & Prob (F-Statistik) \\
\hline $\mathbf{1}$ & 61.00106 & 0.000000 \\
& Sumber: Eviews 9 (diolah)
\end{tabular}

Dari hasil regresi data dalam penelitian ini dapat dilihat bahwa nilai $\mathrm{F}$ hitung adalah sebesar 61.00106 dan untuk $\mathrm{F}$ table dapat dihitung dengan menggunakan tingkat keyakinan 95\%, $\alpha$ $=5 \%$, df1 = k-1: 3-1=2, df2: 90-2=88. Maka dengan $\mathrm{F}$ table 3.10

Rumus hipotesis:

$\mathrm{H}_{0}=$ Pembiayaan Bank Islam dan FDI tidak berpengaruh terhadap Pertumbuhan Ekonomi secara bersama-sama

$\mathrm{H}_{\mathrm{a}}=$ Pembiayaan Bank Islam dan FDI berpengaruh terhadap Pertumbuhan

Ekonomi secara bersama-sama.

Kriteria pengambilan keputusan:

a) Jika $\mathrm{F}$ hitunh $>\mathrm{F}$ table maka $\mathrm{H}_{0}$ ditolak

b) Jika $\mathrm{F}$ hitung < $\mathrm{F}$ table maka $\mathrm{H}_{0}$ diterima

Berdasarkan hasil output diatas maka diperoleh keputusan dan output di atas maka $\mathrm{F}$ hitung (61.00106) > F table (3.10) dengan probabilitas signifikasi $p$-value $<0.05$ yaitu sebesar 0.00000 , karena tingkat signifikansi lebih kecil dari 0.05 maka model regresi dapat digunakan untuk memprediksi variable endogen PDB atau secara bersamaan variable eksogen (IB dan FDI) berpengaruh signifikan terhadap variable endogen. Maka kesimpulannya H0 ditolak dan Ha diterima.

\subsubsection{Hasil Uji t}

\section{Tabel 4. Uji t (Parsial)}

\begin{tabular}{lllll}
\hline Model & Std Error & $\begin{array}{l}\text { Standar } \\
\text { Coefficient }\end{array}$ & t & Prob \\
\hline $\mathrm{C}$ & 2197.958 & 8674.608 & 3.946666 & 0.0002 \\
\hline $\mathrm{X} 1$ & $2.75-\mathrm{E} 05$ & 0.029300 & 10.676595 & 0.0000 \\
\hline $\mathrm{X} 2$ & $2.28 \mathrm{E}+07$ & $2.38 \mathrm{E}+07$ & 1.673192 & 0.0297 \\
\hline \multicolumn{5}{c}{ Sumber: Eviews 9 (diolah) } \\
\end{tabular}

Dari tabel 4 maka dapat dijelaskan sebagai berikut:

1) $\mathrm{T}$ hitung $>\mathrm{t}$ tabel, yaitu $3.9646666>1.6626$ atau nilai prob $\mathrm{t}(0.0002)<\alpha=0.05$ maka pengaruh variable $\mathrm{X} 1$ Pembiayaan Bank Islam (IB) terhadap Variabel Y (PDB) adalah signifikan. Pada tabel 5 didapatkan kiefisien sebesar 0.029300. hasil koefisien menunjukkan bahwa X1 berpengaruh positif terhadap PDB.

2) $\mathrm{T}$ hitung $>\mathrm{t}$ tabel yaitu $1.673192>1.6626$ atau nilai prob $\mathrm{t}(0.0297)<\alpha=0.05$ maka pengaruh variable $\mathrm{X} 2$ (FDI) terhadap Variabel Y (PDB) adalah signifikan. Pada tabel 5 didapatkan koefisien FDI 2.38E+07. Hasil menunjukkan bahwa X2 berpengaruh positif terhadap PDB.

\subsection{Pembahasan dan Hasil Penelitian}

\subsubsection{Pengaruh Pembiayaan Bank Islam dan FDI terhadap PDB secara Simultan}

PDB di Negara OKI secara simultan dan signifikan dipengaruhi oleh Pembiayaan Bank Islam dan FDI. Selain itu juga didapatkan nilai determinasi sebesar $58.37 \%$ dan $41.63 \%$ dipengaruhi oleh variable lain yang tidak diteliti.

Dari hasil penelitian menunjukkan bahwa Pembiayaan Bank Islam dan FDI berpengaruh secara positif terhadap Pertumbuhan Ekonomi suatu Negara. Artinya disini bahwa apabila Pembiayaan Bank Islam yang disalurkan naik atau bertambah maka akan berdampak Perekonomi suatu Negara, Bank Islam dapat memberikan pembiayaan kepada masyarakat untuk suatu usaha sehingga dapat mensejahterakan masyarakat disuatu Negara tersenut. Begitu juga dengan FDI, apabila FDI meningkat diartikan bahwa investasi semakin meningkat dan dapat meningkatkan pertumbuhan ekonomi. Perusahaan-perusahan yang mendapatkan modal dari FDI akan meningkatkan pengoperasian dan produksi sehingga akan berdampak terhadap perekonomian masyarakat.

\subsubsection{Pengaruh Pembiayaan Bank Islam (X1) Terhadap PDB (Y) secara Parsial}

Berdasarkan hasil uji $t$ menunjukkan koefisien variable Pembiayaan Bank Islam Negara OKI sebesar 0.029300, hal ini menunjukkan bahwa PDB akan meningkat sebesar 0.029300 satuan X1. Hasil koefisien ini menunjukkan bahwa X1 berpengaruh positif dan 
signifikan terhadap PDB. Hasil ini sejalan dengan penelitian yang diteliti oleh Astuty (2015) bahwasanya Pembiayaan Bank Islam berpengaruh positif dan signifikan terhadap Pertumbuhan Ekonomi (Astuty, 2015).

\subsubsection{Pengaruh FDI (X2) Terhadap PDB secara Parsial}

Berdasarkan kasul koefisien variable FDI Negara OKI sebesar 2.38E+07, hal ini menunjukkukan bahwa PDB akan menungkat sebesar 2.38E+07 satuan X2. Hasil koefisien ini menunjukkan bahwa $\mathrm{X} 2$ berpengaruh positif dan signifikan terhadap PDB. Hasil ini sejalan dengan penelitian yang dilakukan oleh Pranoto (2013) yang menyatakan bahwa FDI berpengaruh positif dan signifikan terhadap PDB di suatu Negara (Pranoto, 2013).

\section{Kesimpulan}

Berdasarkan hasil penelitian yang telah diuraikan, maka dapat diambil kesimpulan sebagai berikut: Pertama, Terdapat pengaruh secara bersama-sama antara Pembiayaan Bank Islam dan FDI terhadap PDB di Negara OKI dari tahun 2009-2017. Hasil ini ditunjukkan oleh nilai signifikan uji F sebesar 0.00000 lebih kecil dari 0.005. Kedua, Berdasarkan hasil uji t menunjukkan koefisien variable Pembiayaan Bank Islam Negara menunjukkan bahwa X1 berpengaruh positif dan signifikan terhadap PDB. Hasil ini sejalan dengan penelitian yang diteliti oleh Astuty (2015). KetigaBerdasarkan hasil koefisien variable FDI Negara OKI menunjukkukan bahwa X2 berpengaruh positif dan signifikan terhadap PDB. Hasil ini sejalan dengan penelitian yang dilakukan oleh Pranoto (2013).

\section{Ucapan Terimakasih}

Penulis mengucapkan terimakasih kepada orangtua dan dosen-dosen Magister Sains Ekonomi Islam Univesrsitas Airlagga, serta pihak-pihak yang telah membantu dan berkontribusi baik secara langsung maupun tidak langsung dalam penyelesaian penelitian ini.

\section{Daftar Pustaka}

Astuty, W. (2015). Pengaruh Pembiayaan Syariah Terhadap Pertumbuhan Ekonomi di Sumatera Utara. In the 8th International Workshop on Islamic Development (pp. 113). Medan: UMSU Press.
Abduh, M., \& Chowdhury, N. T. (2012). DoesIslamic BankingMatter forEconomic Growthin Bangladesh? Journal of Islamic Economics, Banking and Finance, Vol. 8(No 3), 104-114.

Caporale, G. M., \& Helmi, M. H. (2018). Islamic Banking, Credit and Economic Growth: Some emperical evidence. Wiley, 456-477.

Cetin, H. (2014). Econometric Modeling of Turkish Participatory Banks Deposits. International Journal of Trade, Economics and Finance.

Kalaysi, S., \& Tekin, B. E. (2016). Interactions between Economic Growth, FDI and Islamic Banking Development in Turkey. International Journal of Business and Management.

Lebdaoui, H. (2015). Islamic banking presence and economic growth in Southeast Asia. International Journal of Islamic and Middle Eastern Finance and Management.

Pranoto, O. S. (2013). Pengaruh Ekspor Dan Foreign Direct Investment Terhadap Pertumbuhan Domestik Bruto Indonesia", 49-53.

Owen, E. (2018). Foreign Direct Investment and Elections: The Impact of Greenfield FDI on Incumbent Party Reelection in Brazil. Retrieved from https://doi.org/10.1177/0010414018797936

Owusu-Nantwi, V., \& Erickson, C. (2019). Foreign direct investment and economic growth in South America . Journal of Economic Studies, 383-398.

Rehman, N. U. (2015). FDI and Economic Growth: Emperical Evidence from Pakistan. Journal of Arts, Science \& Commerce, 59-69.

Tajgardoon, G., Noormohamadi, K., \& Behname, M. (2015). Foreign Direct Investment and Islamic Banking: A Granger Causality Test. Economics and Finance Review, 8-13.

UNCTAD. (2000). United Nations Conference on $\mathrm{T}$ Rade and Development World Investment Report 2000 Cross-Border Margers and Acquisitions and Development.

Zarrouk, H., Ghak, T. E., \& Haija, A. A. (2017). Financial development, Islamic finance and economic growth: evidence of the UAE. Journal of Islamic Accounting and Business Research, Vol. 8(Issue 1), 2-22. Retrieved from https://doi.org/10.1108/JIABR-052015-0020 